\title{
استحداث تصميمات زخرفية على أساس التراكيب النسجية البسيطة لإثراء هادتي التصميم والنسيج لطلاب التربية الفنية
}

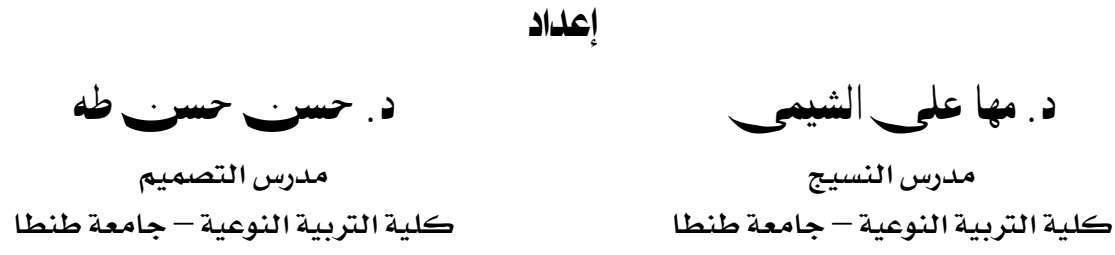

مجلة بحوث التربية النوعية - جامعة المنصورة

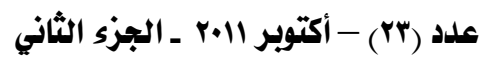




\section{استحداث تصميسمات زخرفية على أساس التراكيب النسجية البسيطة}

\section{لإثراء هادتي التصميم والنسيج لطلاب التزبية الفنية}

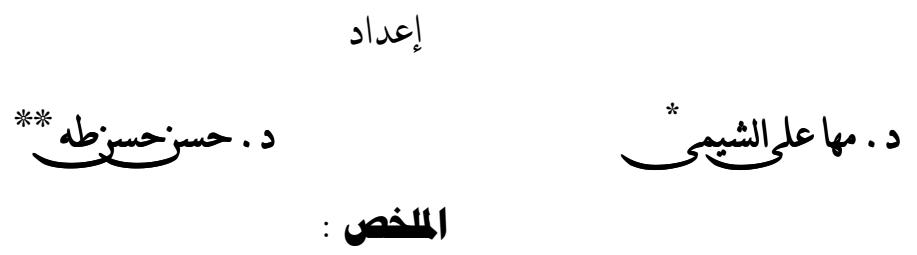

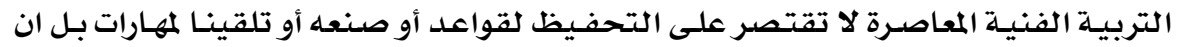

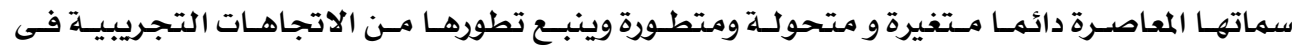

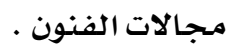

وفى مجال التعاون والربط بين مجالات الفنون ومنها (التصميهم / النسيج )

يحاول الباحثان من خلال هلذه الدراسة استثمار التراكيب النسيجية البسيطة ،والتى يهكن

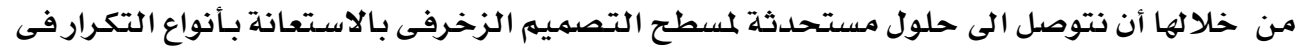

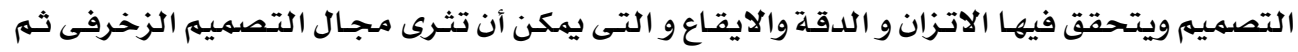

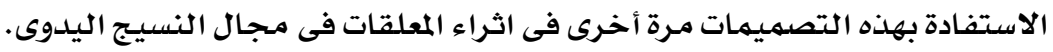

$$
\text { و أهم النتائج التي توصل إليها البحث هى : }
$$

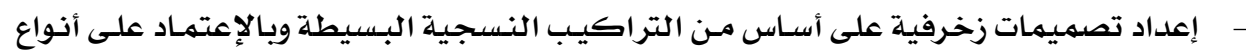

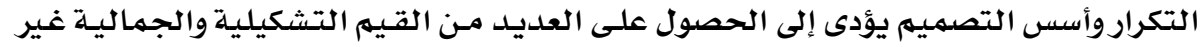

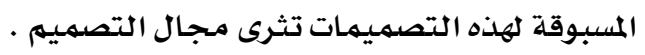

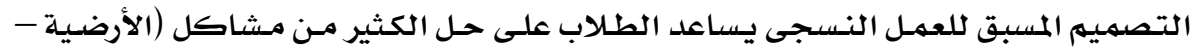

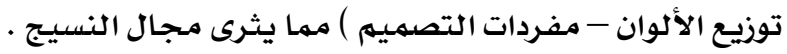

* مدرس النسيج كلية التربية النوعية - جامعة طنطا ** مدرس التصميم كلية التربية النوعية - جامعة طنطا 


\section{Research summary}

\section{THE DEVELOPMENT OF DECORATIVE DESIGNS ON THE BASIS OF SIMPLE TEXTILE STRUCTURES TO ENRICH THE SUBJECTS OF DESIGN AND TEXTILE FOR STUDENTS OF ART EDUCATION}

Contemporary art education is not limited to the memorization of rules or made or received, but the skills of contemporary features that are always changing and shifting, sophisticated and development stems from the experimental trends in the fields of the arts.

In the field of cooperation and linkage between areas of the arts, including (design/ fabric)

Trying to researchers in this study investment structures textile simple, and that which they can reach a solution developed to flat decorative design using the types of redundancy in the design and checks the balance and accuracy and rhythm, which can enrich the field of decorative design and make use of these designs again in the enriched hanging in the field of weaving.

The most important findings of the research are:

- Preparation of decorative designs on the basis of simple textile structures depending on the types of redundancy and the foundations of design leads to access to many of the values of plastic and aesthetic unprecedented for these designs enrich the field of design.

- Pre-design to work woven helps students solve many problems (ground - the distribution of colors - vocabulary design), which enriches the field of weaving. 


\section{استحداث تصميسمات زخرفية على أساس التراكيب النسجية البسيطة \\ لإثراء هادتي التصميم والنسيج لطلاب التربية الفنية}

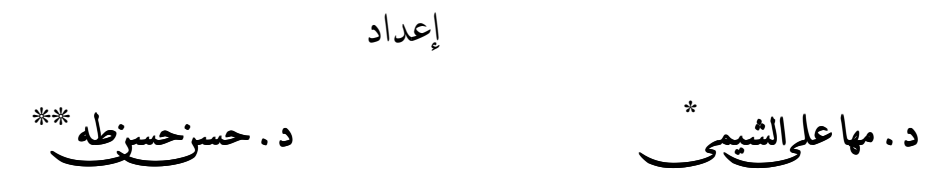

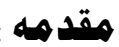

التربيـة الفنيـة المعاصـرة لا تقتصر على التحفيظ لقواعد أو صـنعـه أو تلقينـا لمهارات بـل ان ان

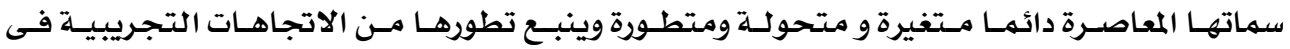

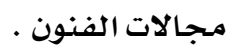

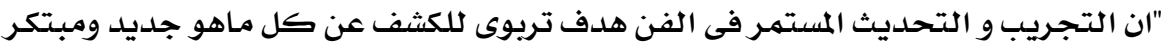

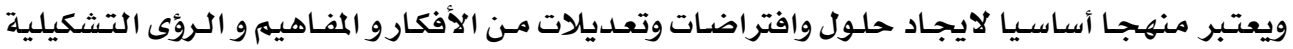

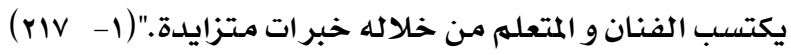
وتعد التراكيب النسجيه أساس بناء المنسوج التي يمكن من خلالها تحقيق قيما جماليه في النى

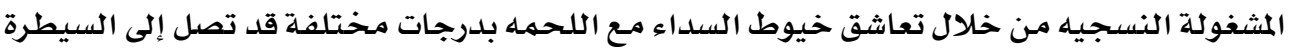

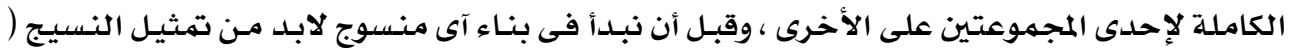

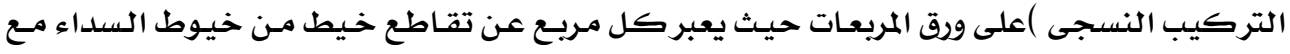

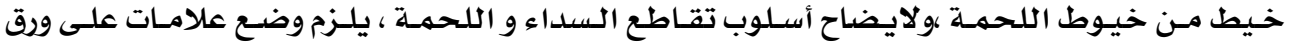

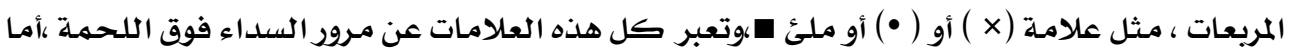

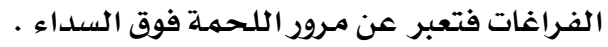

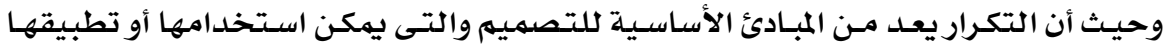

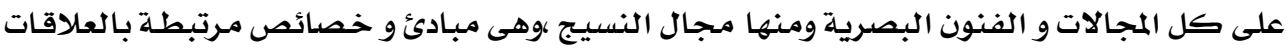

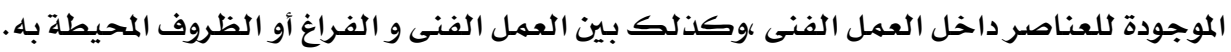

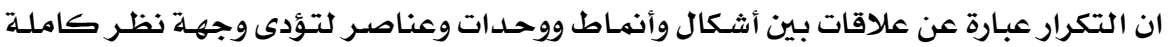

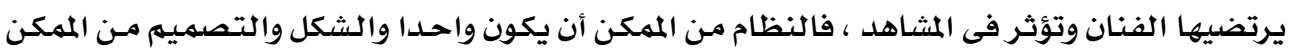
أن يتغيربتغير شكل التركيب النسجى من شكل آلـآخر. وفى مجال التعاون والريط بين مجالات الفنون ومنها (التصميم / النسيج ).

* مدرس النسيج كلية التربية النوعية - جامعة طنطا ** مدرس التصميم كلية التربية النوعية - جامعة طنطا 


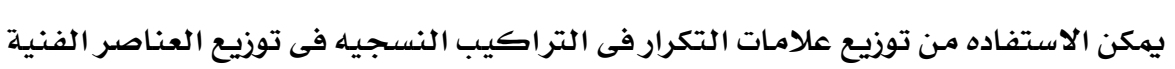

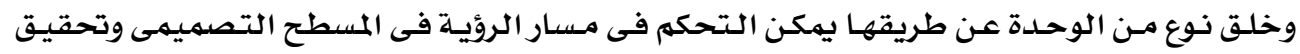

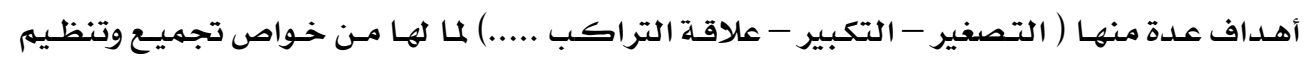
الوحدات الزخرفية لاحداث الايقاع والتنظيم بطريقة غير تقلير التهيدية.

ومن هنا جاءت فكرة البحث الحالى فى استثمار التراكيب النسجية البسيطة ،والتى يهكن

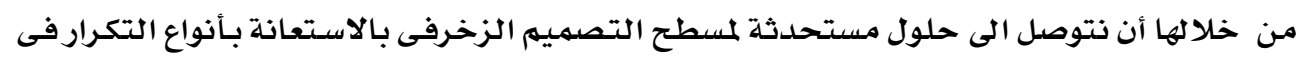

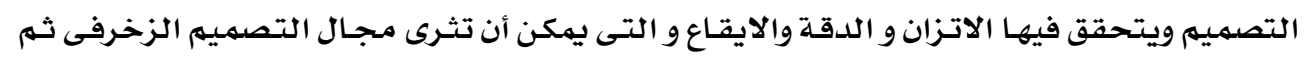

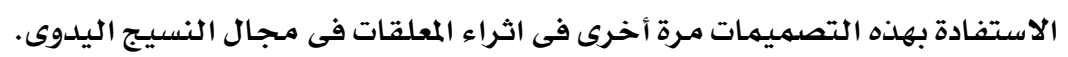

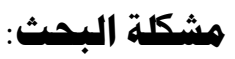

لـوحظ مـن خـلال التـدريس لطلبـة الفرقـة الأولى - قـسم التربيـة الفنيـة - كليـة التربيـة

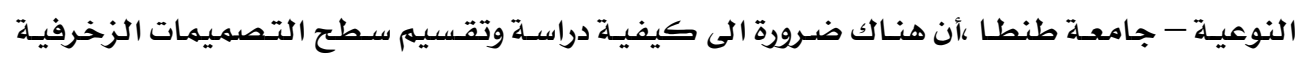

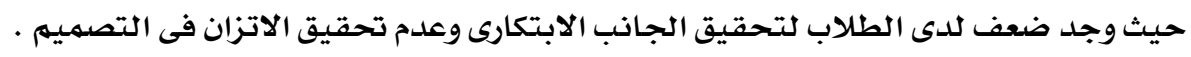

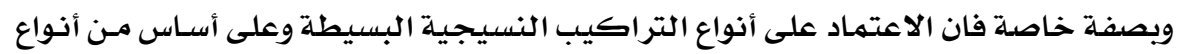

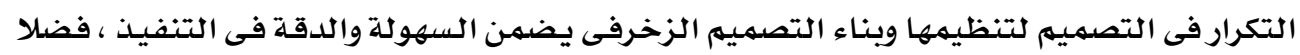

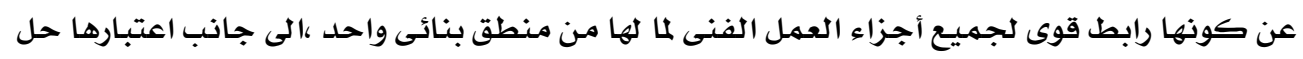

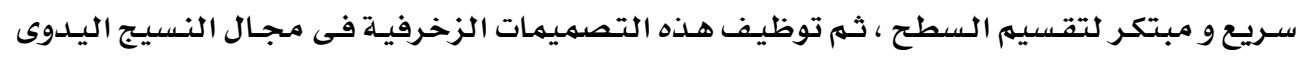

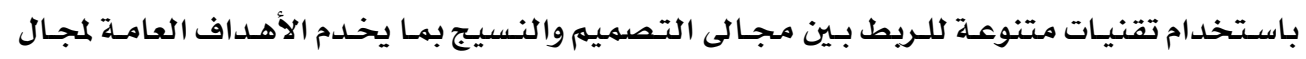
التربية الفنية . باستخدات

$$
\text { وبناءا على ذلك تتلخص مشكلة البحث فى التساؤلين الآتيين : }
$$

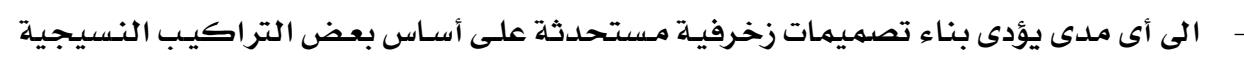

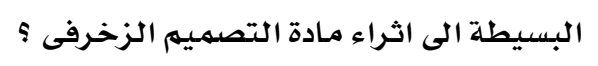

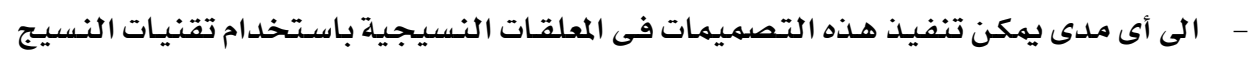

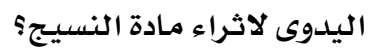

$$
\begin{aligned}
& \text { أهميهة البمث : } \\
& \text { ترجـع أهمية هذا البحث إلى : }
\end{aligned}
$$

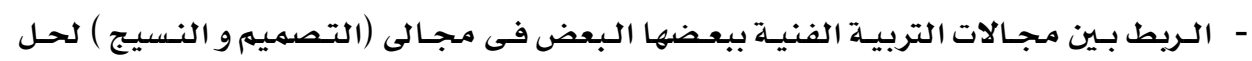

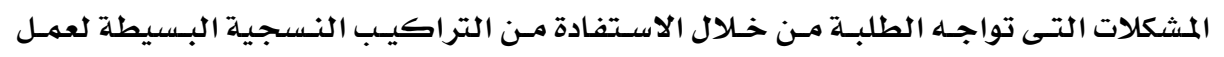

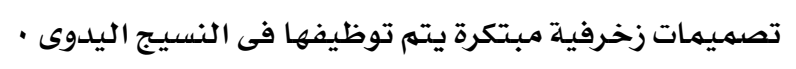

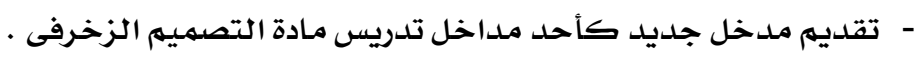


• استثمار التراكيب النسجية البسيطة كأسلوب مستحدث في بناء تصميمات زخرفيـة قائمسة

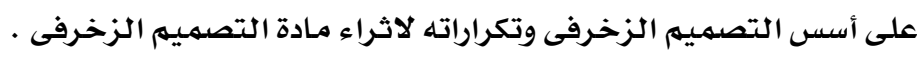

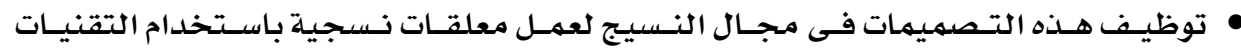

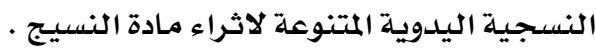

\section{فروض البحث :}

للاجابة على التساؤليين السابقين يفترض الباحثان مايلى :

ه أن بنـاء تصميمات زخرفيـة مستحدثة على أسـاس بعض التراكيب النسجية يؤدى الى اثراء

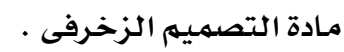

• أن تنفيذ هذه التصميمات فى معلقات نسجية باستخدام تقنيات النسييج اليدوىى يؤدى لاثراء

مادة النسيج

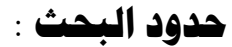

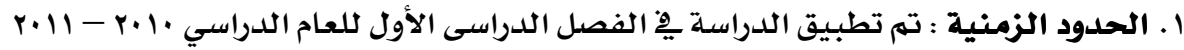
r. الحدود المكانية :كلية التربية النوعية - قسم التربية الفنية - جامعة طنطا

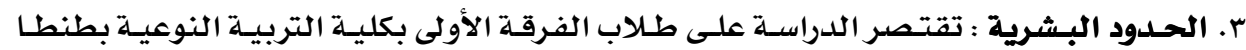

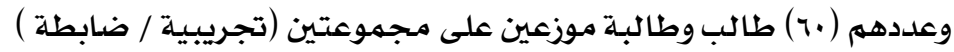
هنهج البحث : وعند

يعتمد البحث الحالى على المنهجين (الوصفى - التجريبي) من خلال الاطارين التاليين: أولا : الإطار النظرى :

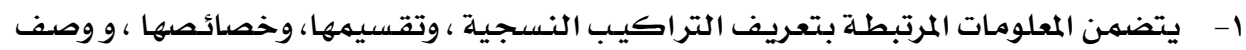

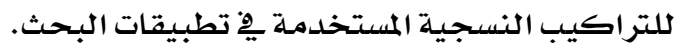

r- وصف و تحليل لأنواع التكرار ِِّ التصميم و دورها ِِّ التصميمات الزخرفية.

ثانيا : الإطار العملى :

هِْ ضوء الإطار النظري السابق يقوم الباحثان بتطبيق تجربة طلابية كهما يلى:

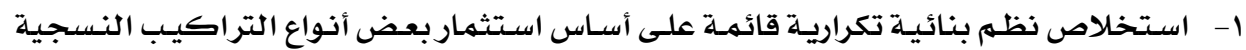

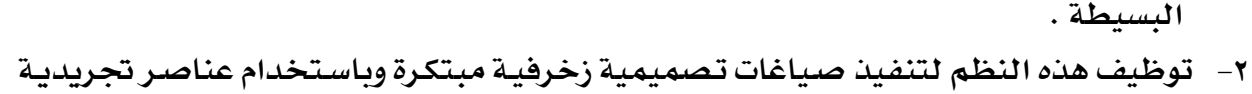
من الطبيعة. ץ- تنفيذ هذه التصميمات الزخرفية ِِّ عمل معلقات نسجية باستخدام تقنيات النسيج اليدوى.

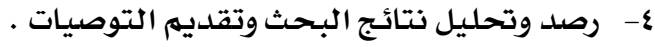


تم اختيـار عينـة البـحـث مـن طلاب الفرقـة الأولى تربيـة فنيـة بكليـة التربيـة النوعيـة بطنطا

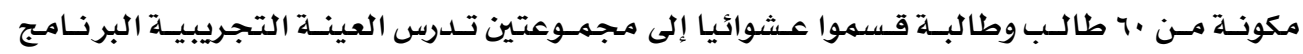

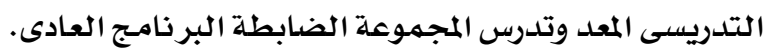

أدوات البحث المع وتكر

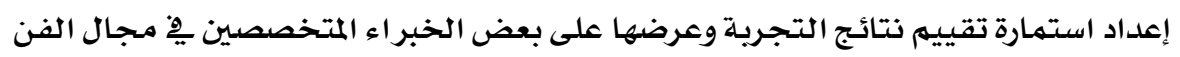
و التربية الفنية والتأكد من صدق وثبات الأداة .

الخاهات المستخدهة:

ورق مـريعـات - ورق كلـك - ورق الكانسسون المقـوى - ألـوان جـواش - مجموعـه مـن

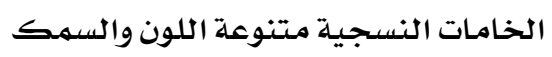

الآلات والمعدات: المات النسجية

نول النسيج اليدوى (البرواز )- ابر مختلفة الحجم - مشط لضمى اللحمه - مقص .

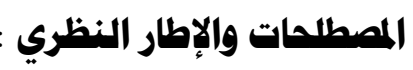

المحور الأول : التراكيب النسيجية

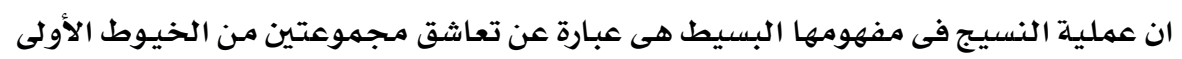

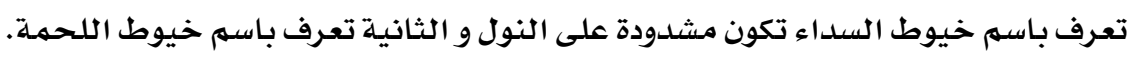

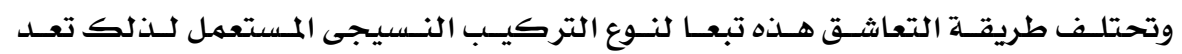

التراكيب النسيجية أساس بناء المنسوج.

فتظهر أحيانـا خيـوط السـداء مسيطرة على سطح القهـاش ويسيمى نسيج ذو تأثيرات مـن

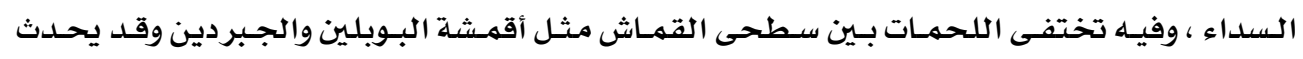

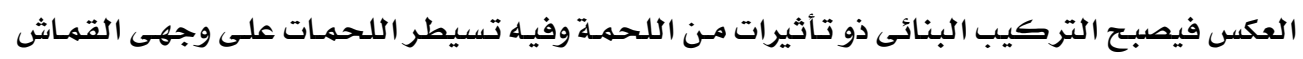

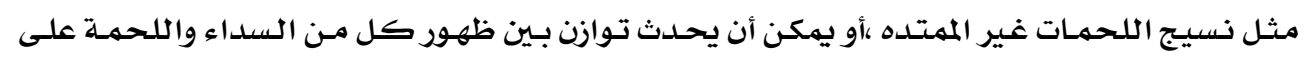

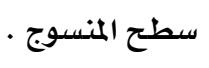

ويمكن تقسيم التراكيب النسيجية الى ثلاثة أنواع أساسية :

ا- التراكيب النسيجية الأساسية : 
وهـى التراكيسب التـى يتقـاطع فيها السـداء مـع اللحمهـة تقاطعـا واحسا ويتسساوى فيها عـدد خيـوط ســـاء التكـرار مــع عـدد خيـوط لحمــات التكـرار وتشهمل ثلاثـة أنـواع وهـى ( الـسـادة والـبـرد و الأطلس)

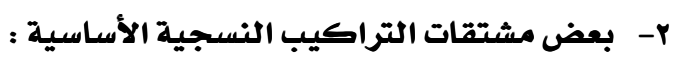

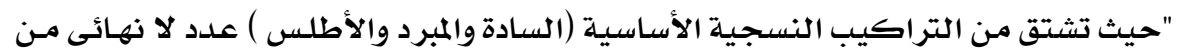

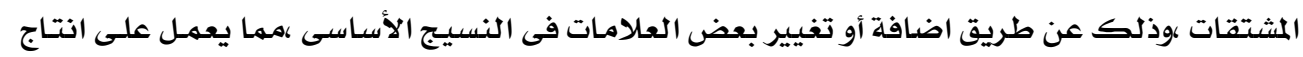

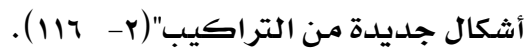

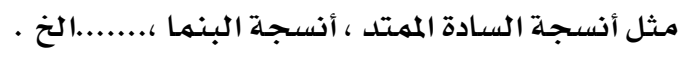
r- بعض التراكيب الناتجة من اتحاد أكثر من تركيب نسجى :

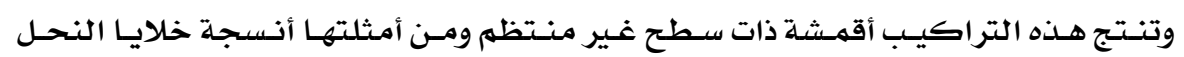

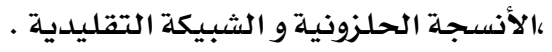
خصائص التركيب النسجى :

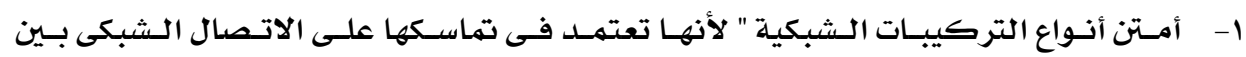

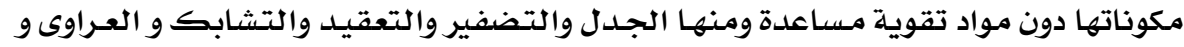

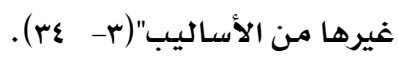
r- أسهل أنواع التركيبات المستخدمة في تكوين السطوح والأجسام وأكثرها سرعة فى التنفيــ و ذلك لعدم احتياجها مساعدة لتقوية البناء .

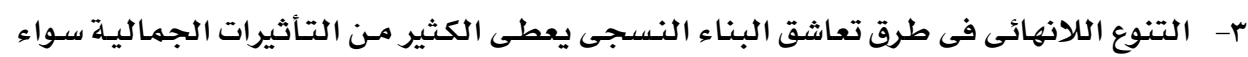

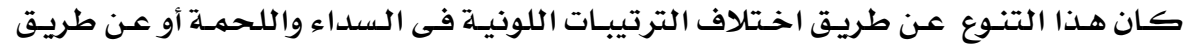
اختلاف الخامات.

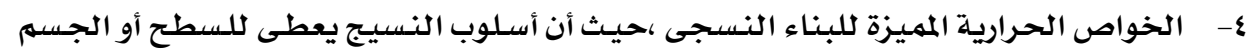

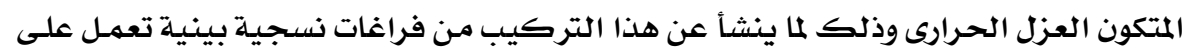

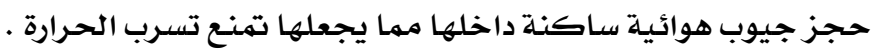
التراكيب النسجية المستخدمة فى تطبيقات البحث:

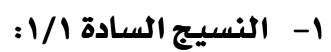

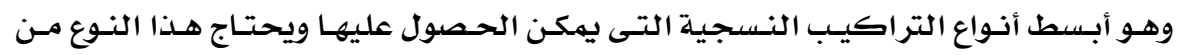

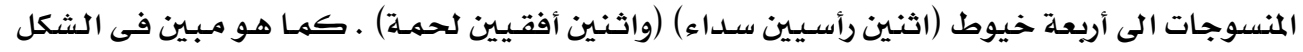

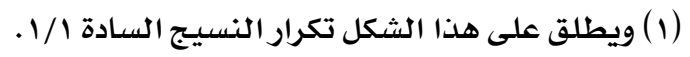

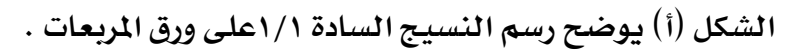

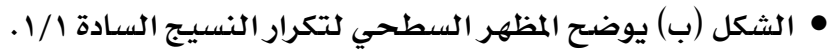




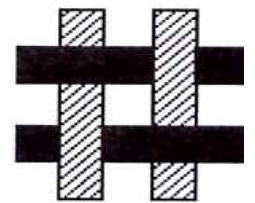

(ب)

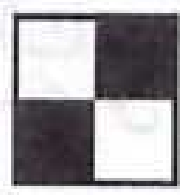

(i)

الشكل (1)

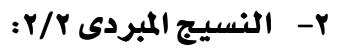

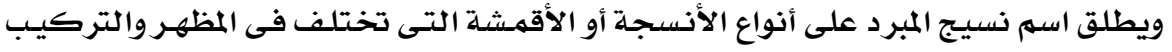

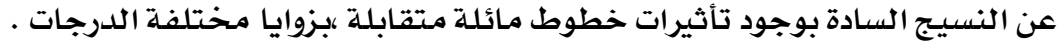

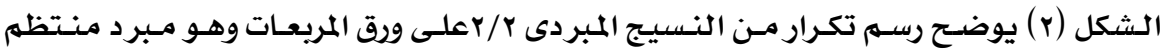
متزن .

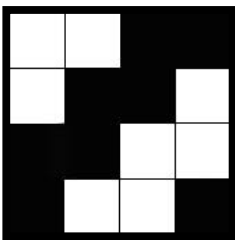

الشكل(ץ)

$$
\text { r r النسيج المبردى r }
$$

وهو غير منتظم متزن ويتكرر على ( خيوط سلداء ، خيوط لحمـة ) و الشكل (r) يوضح رسم

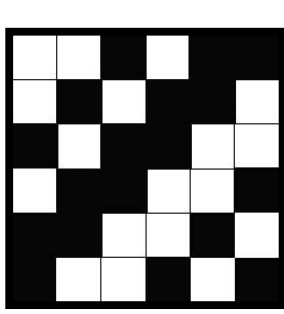

تكرار من هذا النسيج على ورق المريعات .

الشكل(r)

ع- نسيج مبرد مكسور :

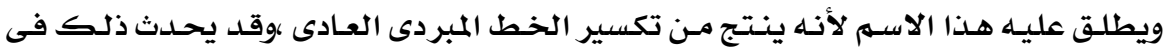

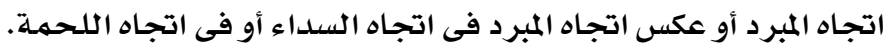

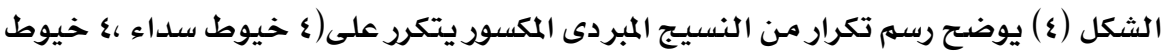

لحمة ) على ورق المربعات . 


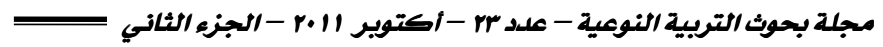

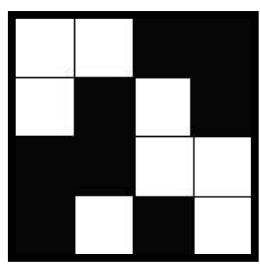

الشكل(ع)

ه- نسيج لمبردى مختلط :

هو نوع مـن أنواع نسيج المبرد ويطلـق عليـه هـذا الاسـم لأنـه يتكون مـن خلـ أو مـزج نـوع مـن

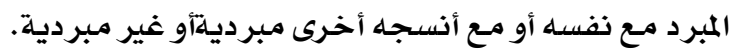

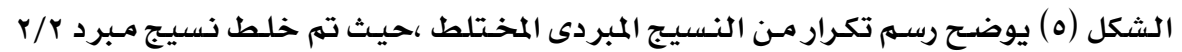

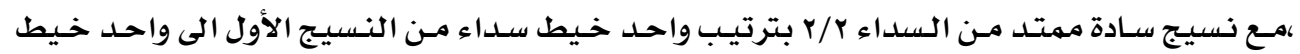

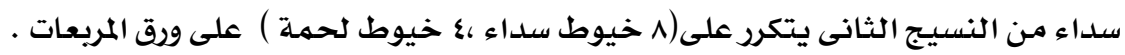

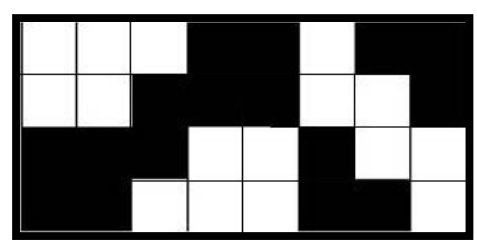

(0) الشكل)

: - نسيج خامهة

وهى مـربعات منقوشة تشبـه زهر الطاولة تظهر على سطح واحسد أو سـطحى الأقهـشة بحسب

الطريقة أو الطرق التى اتبعتفى الحصول عليها.

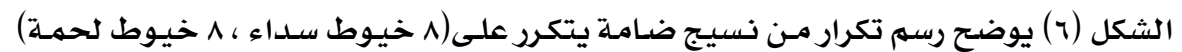

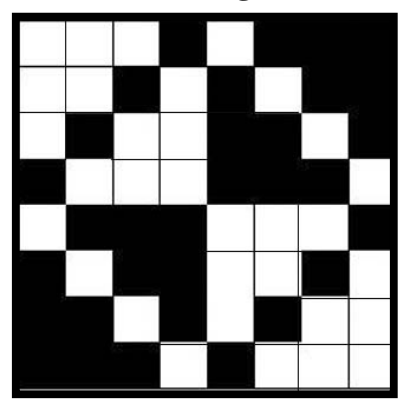

على ورق المربعات .

الشكل(ד)

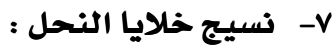

وأطلق عليه هذا الاسهم لأنه يشبـه فى مظهره خلايا النحل . 
الشكل (v) يوضح رسم تكرار من نسيج ضامـة يتكرر على (17 خيوط سداء ،17 خيوط لحمـة )

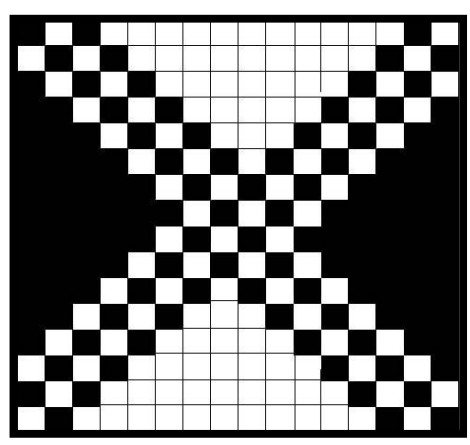

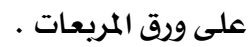

(v)(الشكل)

المحور الثانى : أنواع التكرار والتصميم الزخرفى:

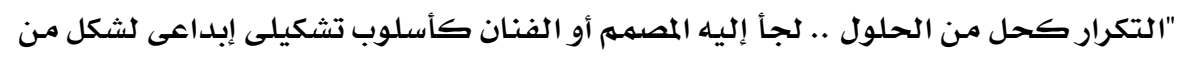

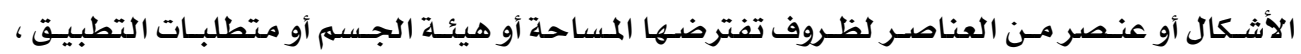

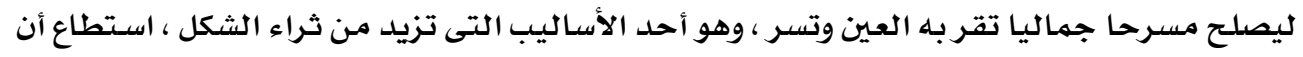

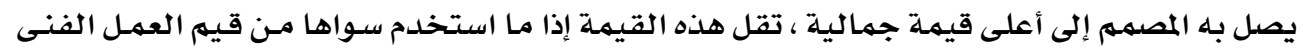
(V) الأخرى . (

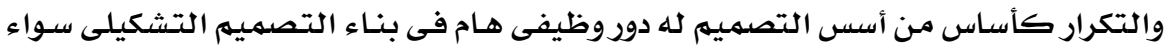

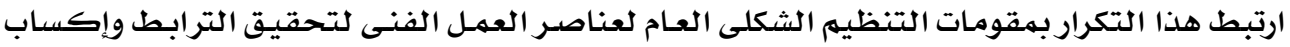

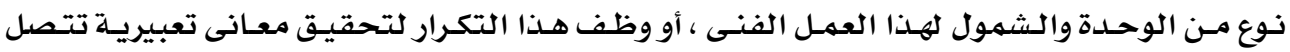

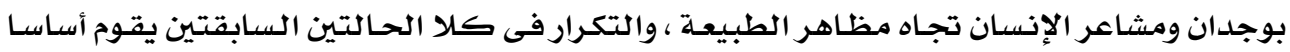

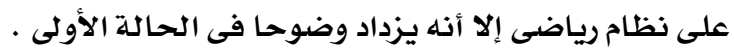

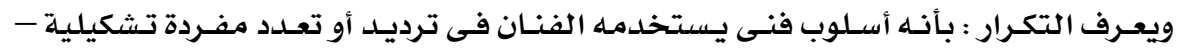

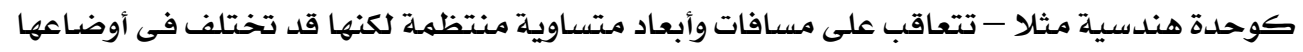
على المسطح التشكيلى .

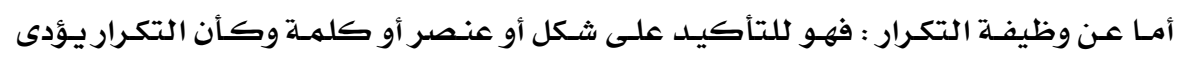

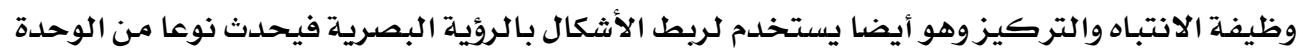

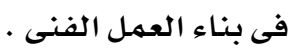

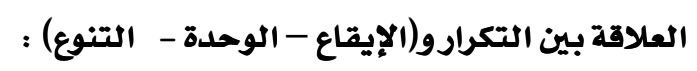

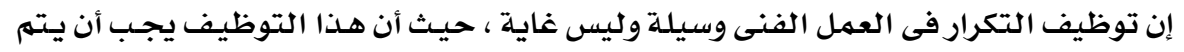

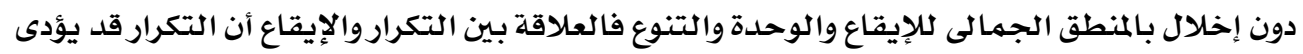

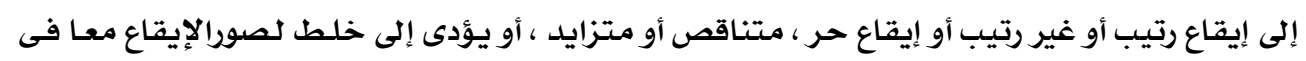




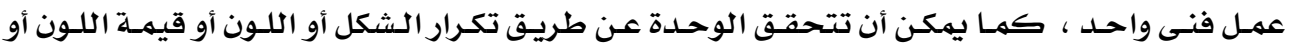

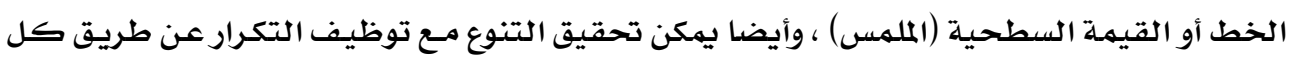

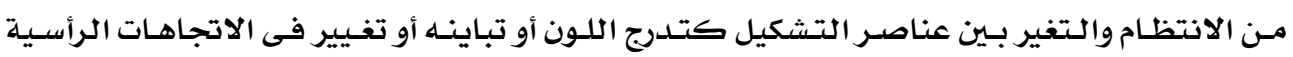

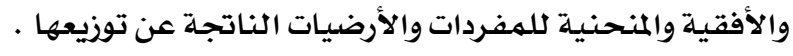

التكرار ووعلاقة الجزء بالجزء :

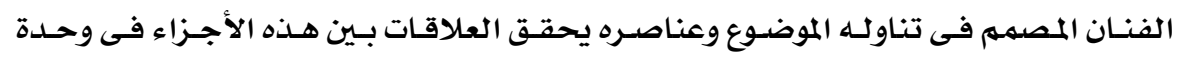

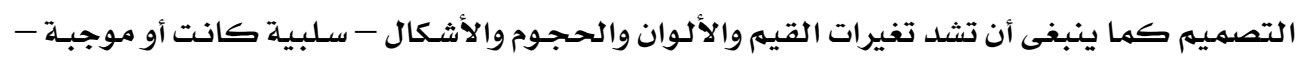

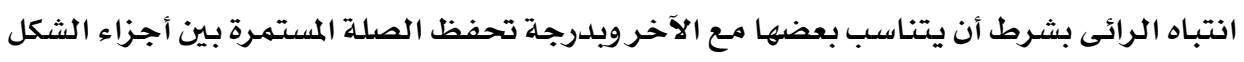
التكرار وعلاقة الجزء بالكل :

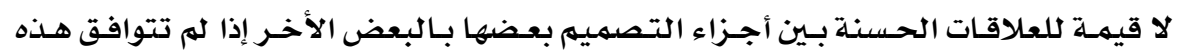

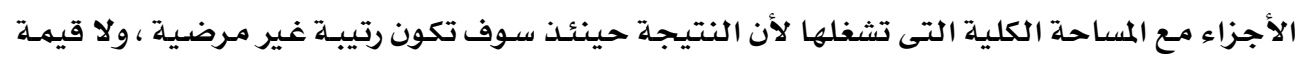

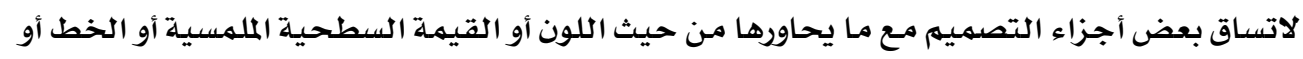

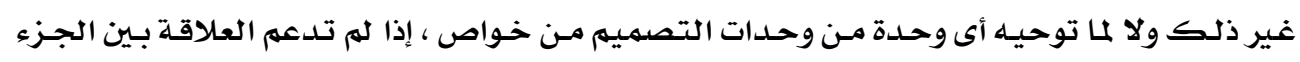

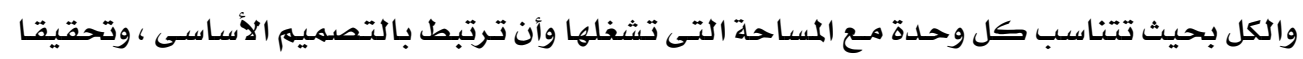

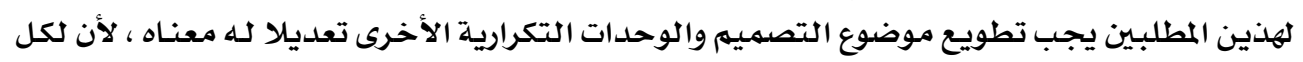

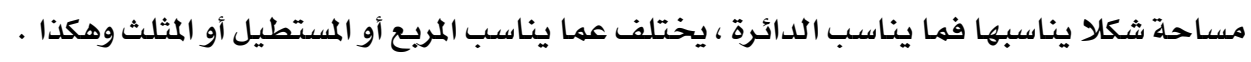

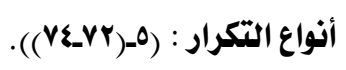

هناك خمس أنواع (أساليب) أساسية للتكرار، ويهكن ابتكار أنواع أخرى من خلال المزج بينها:

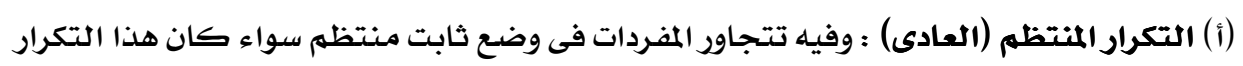

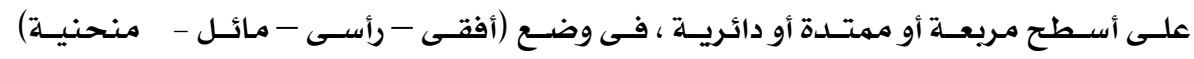
( شكل-

(ب) التكرار العكسى : وفيه تتجاور الوحدات فى أوضاع مغايرة إلى أسفل وأعلى،أو اليمـين واليسار

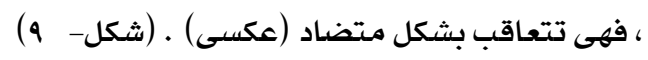

(ج) التكرار المتبادل : يعنى اشتراك أو استخدام مفردتين تشكليتين - أو أكثر - تختلف مصادرها

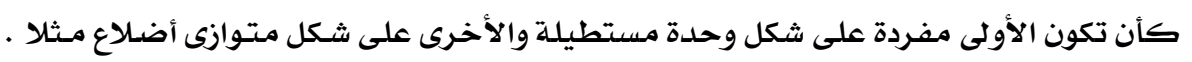

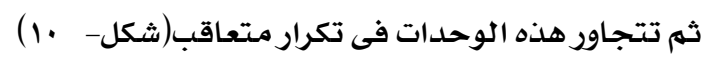

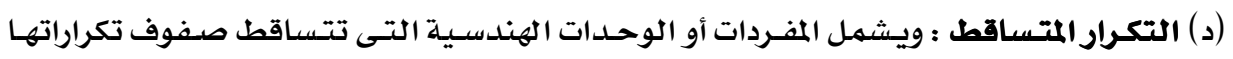

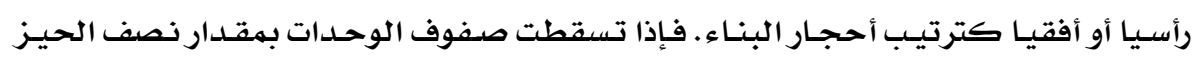

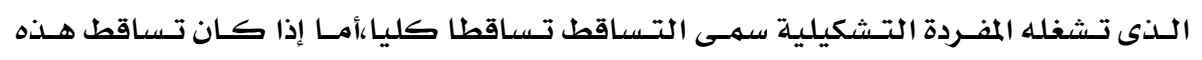

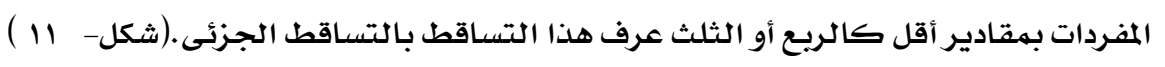


(ه) التكرار المتوالد : يقصد به التكرار المنتظم لمفرده تشكيلية ينشأ عن تجاور أو تعاقب مجموعة

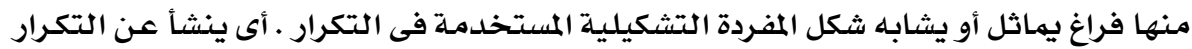

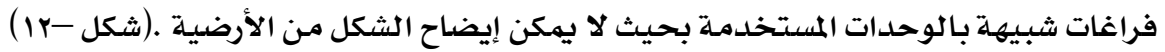

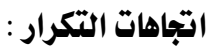

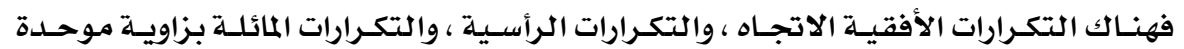

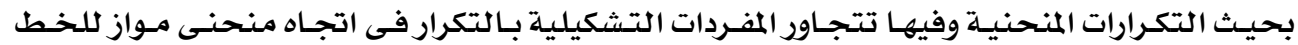

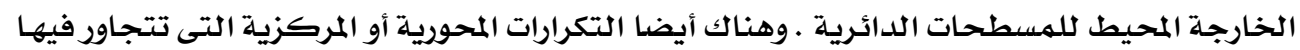

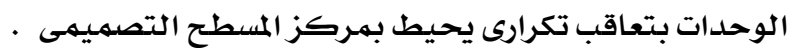

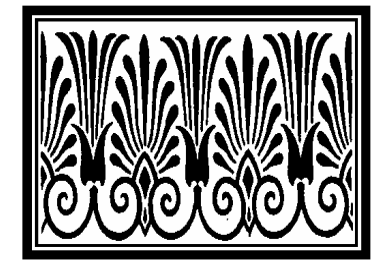

(1.) (1) (1)

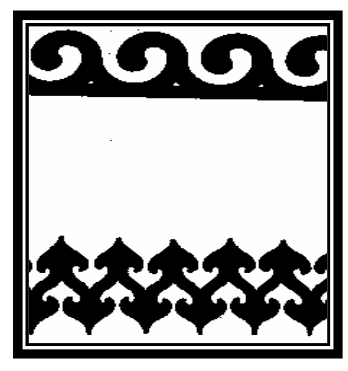

الشكل(r)

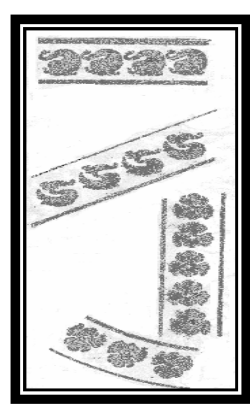

الشكل(^)

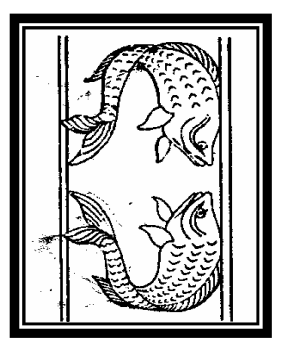

(ه) (الشكل)

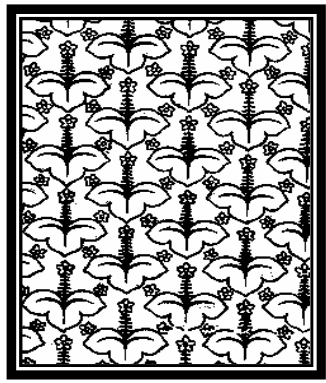

(11)( 


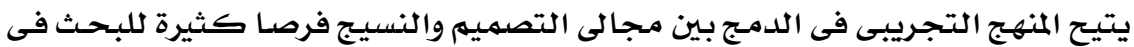

التراكيب النسجية والكثف عن طاقاتها التشكيلية وإستثمارها مـن خـلال مبـادىء التصميهم العامـة (خاصدة التكرارات) للوصول إلى معالجات تشكيلية مبتكرة وخلق قيهم فنيـة وعلاقات تبـادليـة ذات تأثير

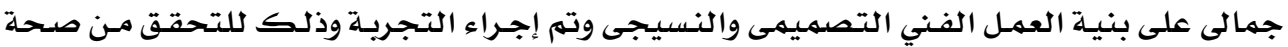

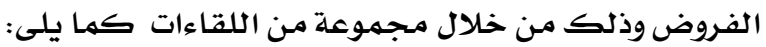

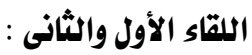

• فى مجال النسيج) يهدف إلى تعريف الطالب مفهوم عملية النسيج واختلاف طريقة التعاشق تبعا لنوع التركيب النسجى المستعمل وكيفية توقيع التركيب النسجى على ورق المربعات . • (فى مجـال التصميم) تحسوير وتعـديل وتبسيط في خطوط ونسب وعلاقـات وألـوان عناصـر

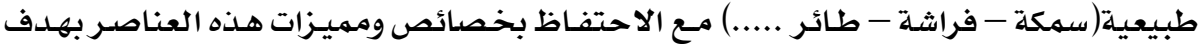

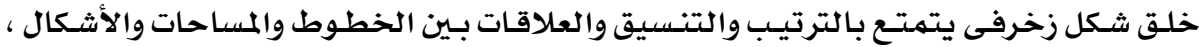
ليعطى عمل فنى ابتكارى .

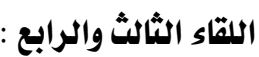
• (فى مجال النسيج) استكمالا للقاء السابق حيث يتم التعـرف على تراكيب نسيجية أكثر و

$$
\text { كيفيية توقيعها على ورق المربعات . }
$$

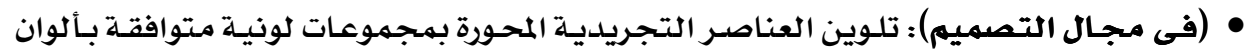

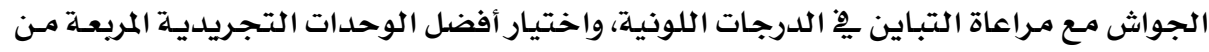

$$
\text { هذه العناصر. }
$$

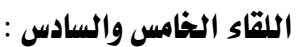

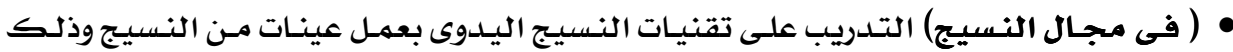

$$
\begin{aligned}
& \text { باستخدام خامات نسيجية مختلفة مالفي }
\end{aligned}
$$

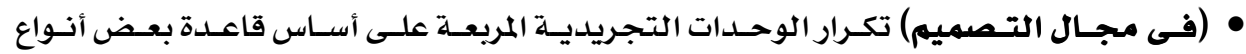

$$
\begin{aligned}
& \text { التراكيب النسيجية البسيطة التى تم التعرف عليها فى اللقاءات السابقة. }
\end{aligned}
$$

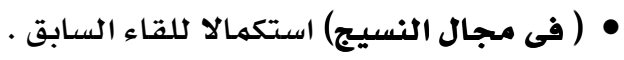

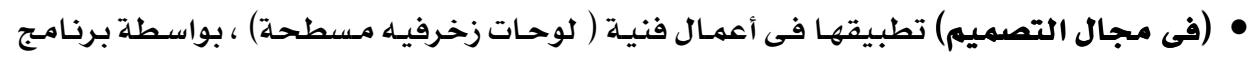

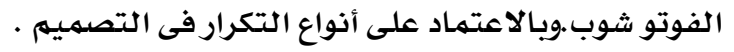




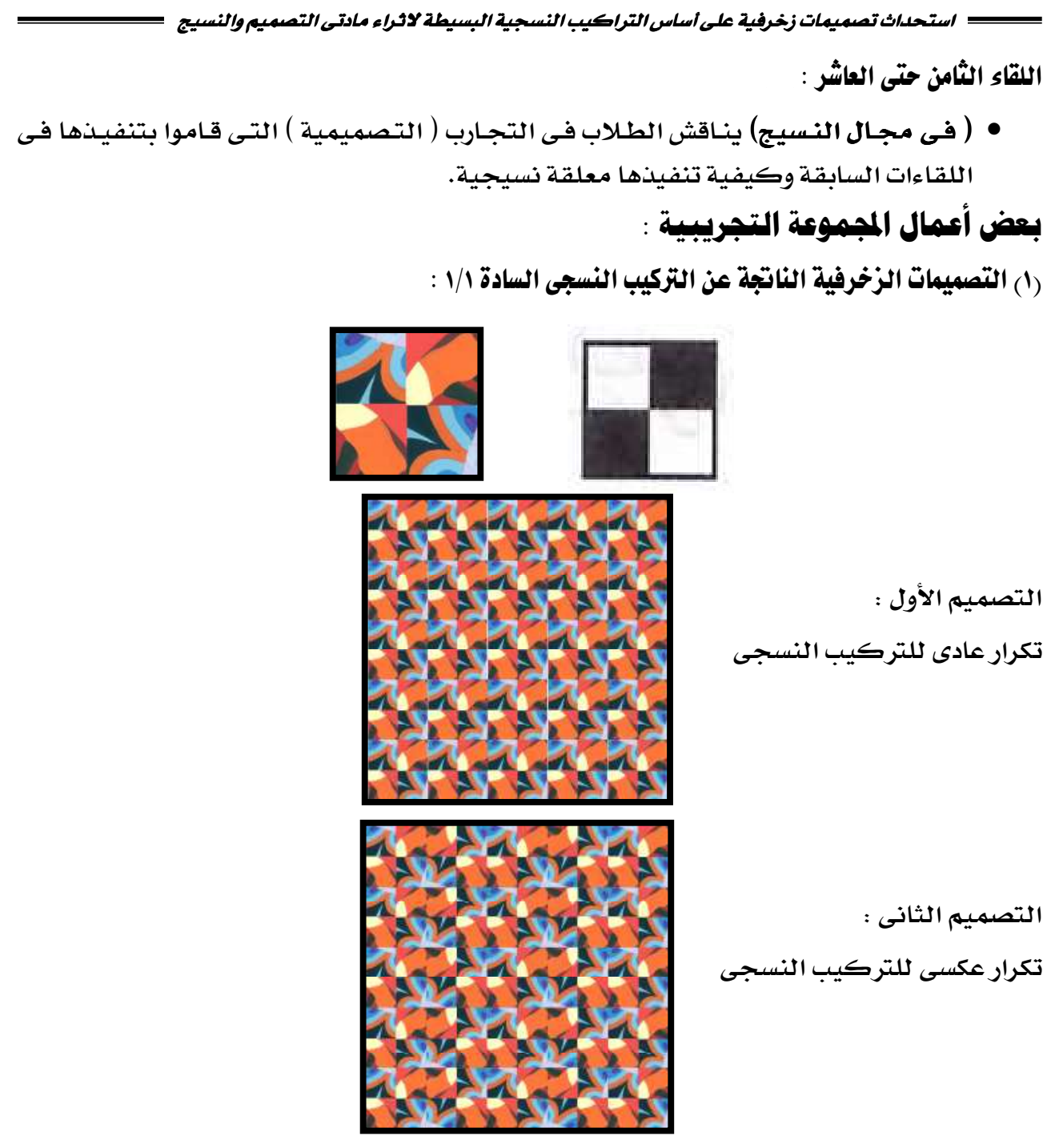

(r) التصميمات الزخرفية الناتجة عن التركيب النسجى مبرد r/r :
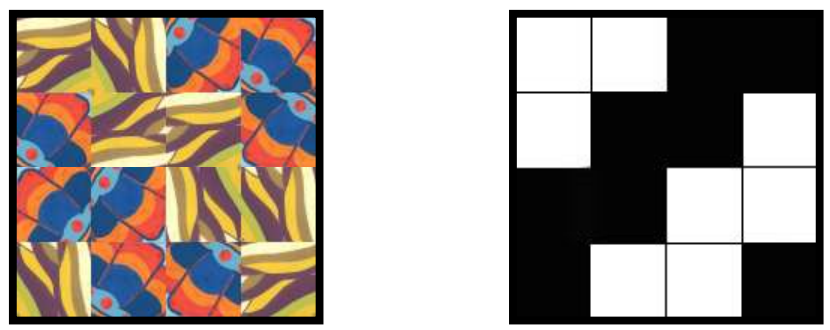


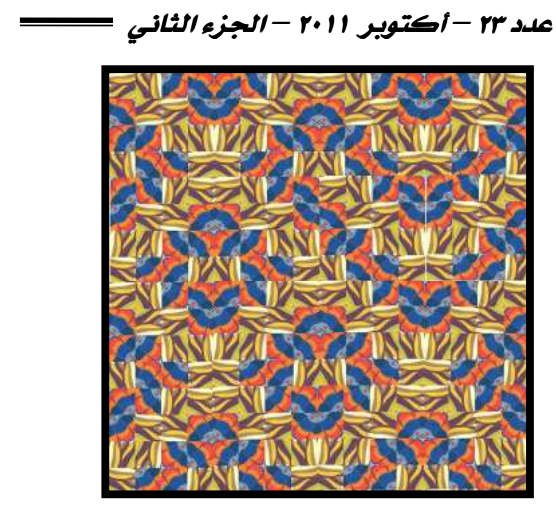

$$
\text { تكرار عكسى للتركيب النسمى الثانى : }
$$

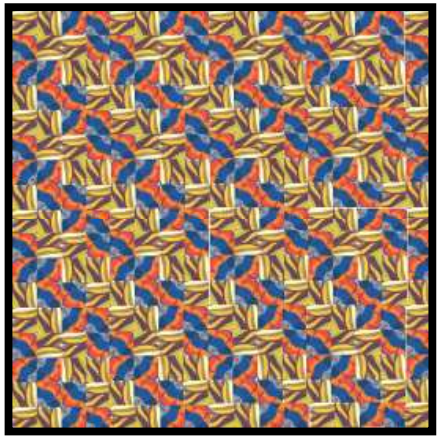

$$
\text { تكرارعادى للتركيب النسميم الأول : }
$$

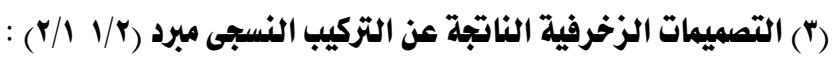
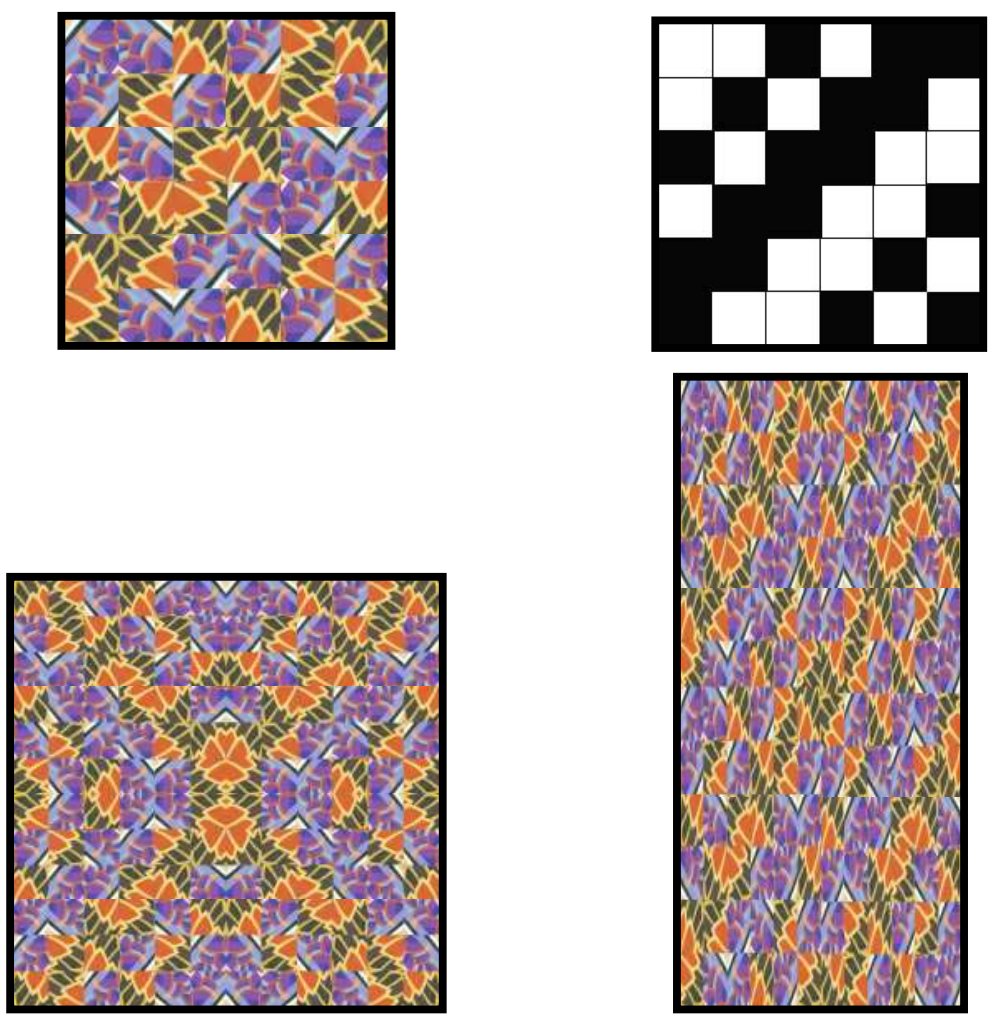

$$
\text { التصميم الأول : - الأ }
$$

تكرار عكسى مـع قلب التركيب النسجى

تكرار عادى مـع الإستطالة للتركيب النسجى 
() التصميمات الزخرفية الناتجة عن التركيب النسجى المبرد المكسور :

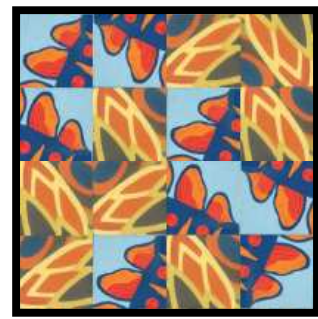

التصميم الثانى

تكرار عكسى للتركيب النسسى

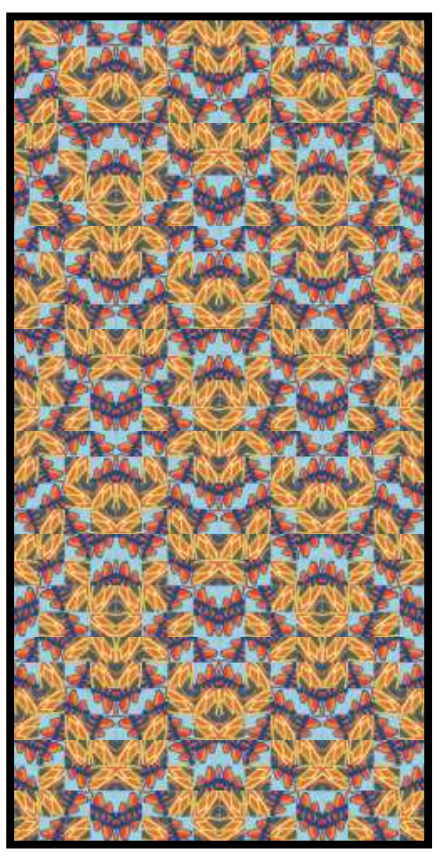

(0) التصميمات الزخرفية الناتجة عن التركيب النسجى مبرد مختط مع سادة :

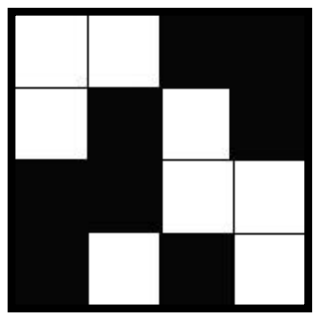

$$
\text { التصميم الأول : }
$$

تكرار عادى للتركيب النسبى
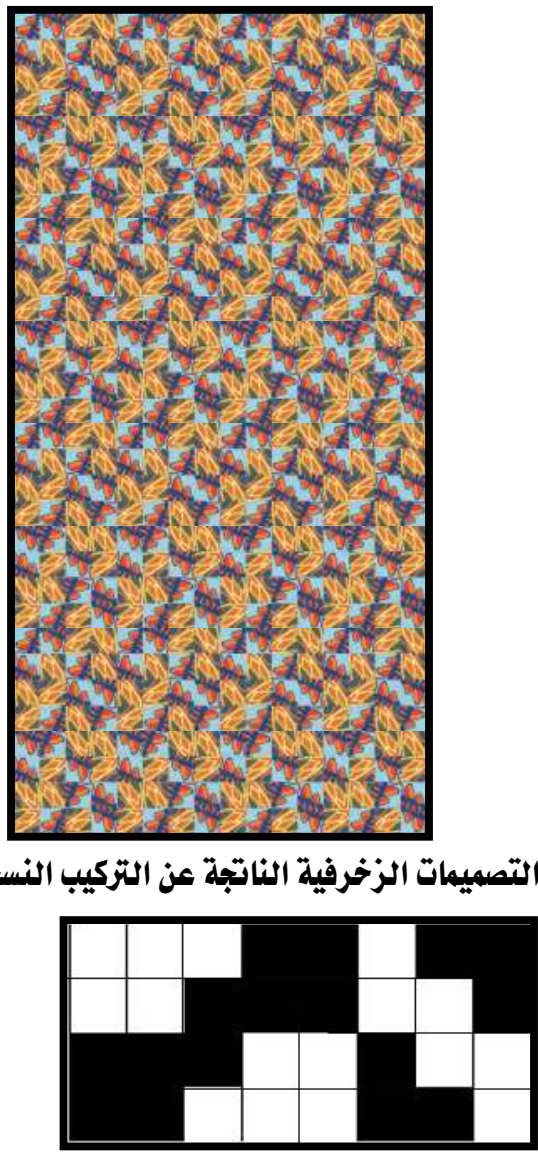

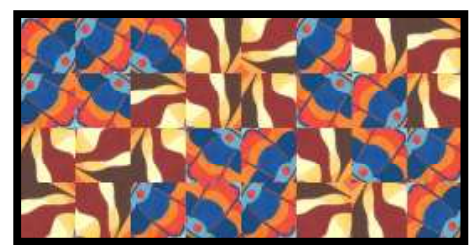




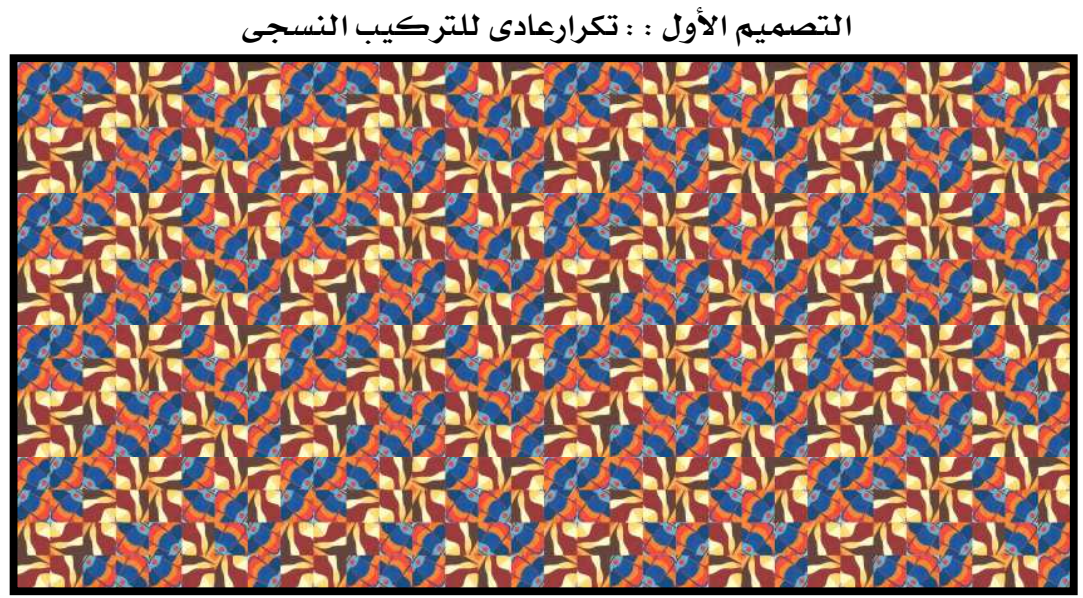

التصميهم الثانى : : تكرارعكسى للتركيب النسجى

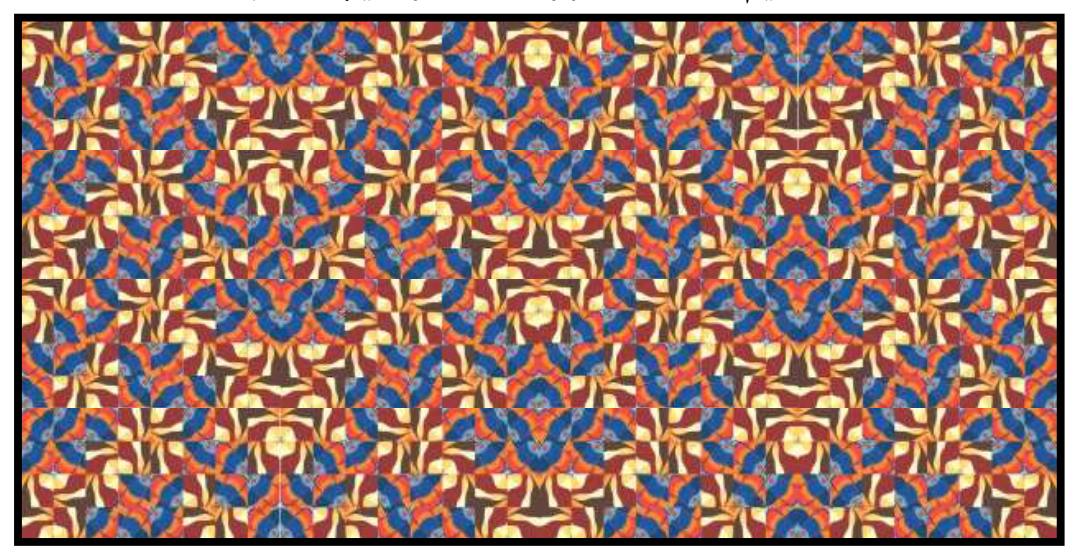

(1) التصميمات الزخرفية الناتجة عن التركيب النسجى (الضامة) :
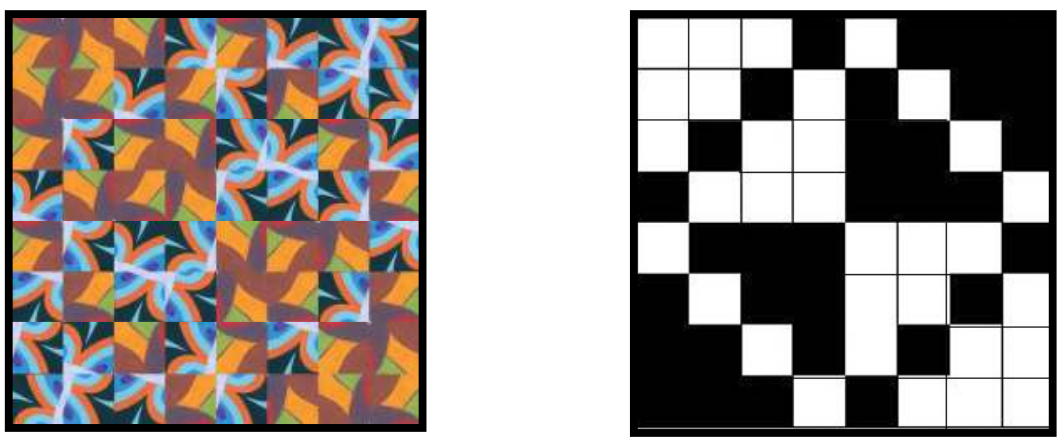

\section{$1 Y \leqslant V$}




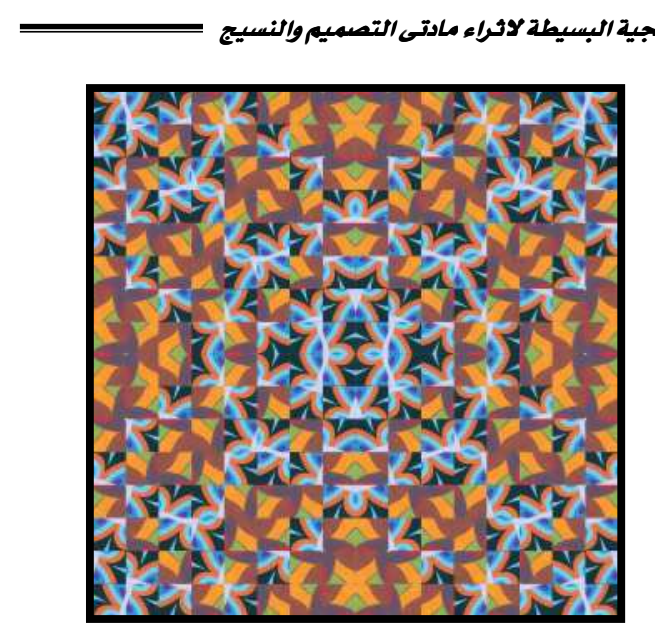

$$
\begin{aligned}
& \text { التصميم الأول : } \\
& \text { تكرار عكسى للتركيب النسجى }
\end{aligned}
$$

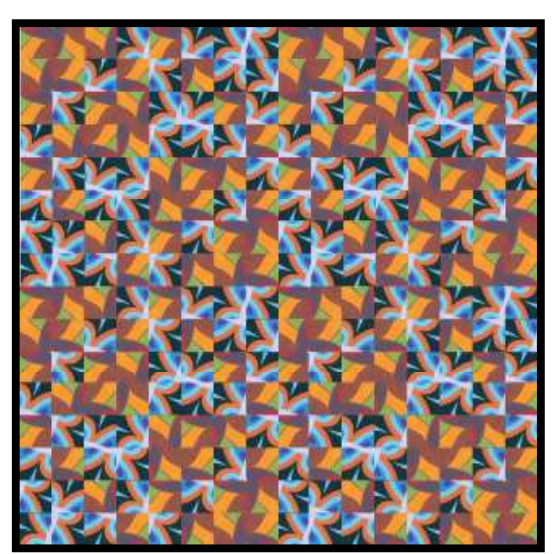

$$
\text { التصميهم الأول : التصت }
$$

$$
\text { تكرار عادى للتركيب النسجى الاول : }
$$

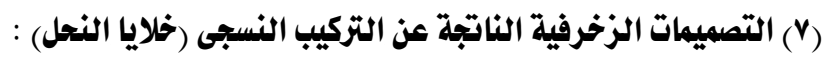
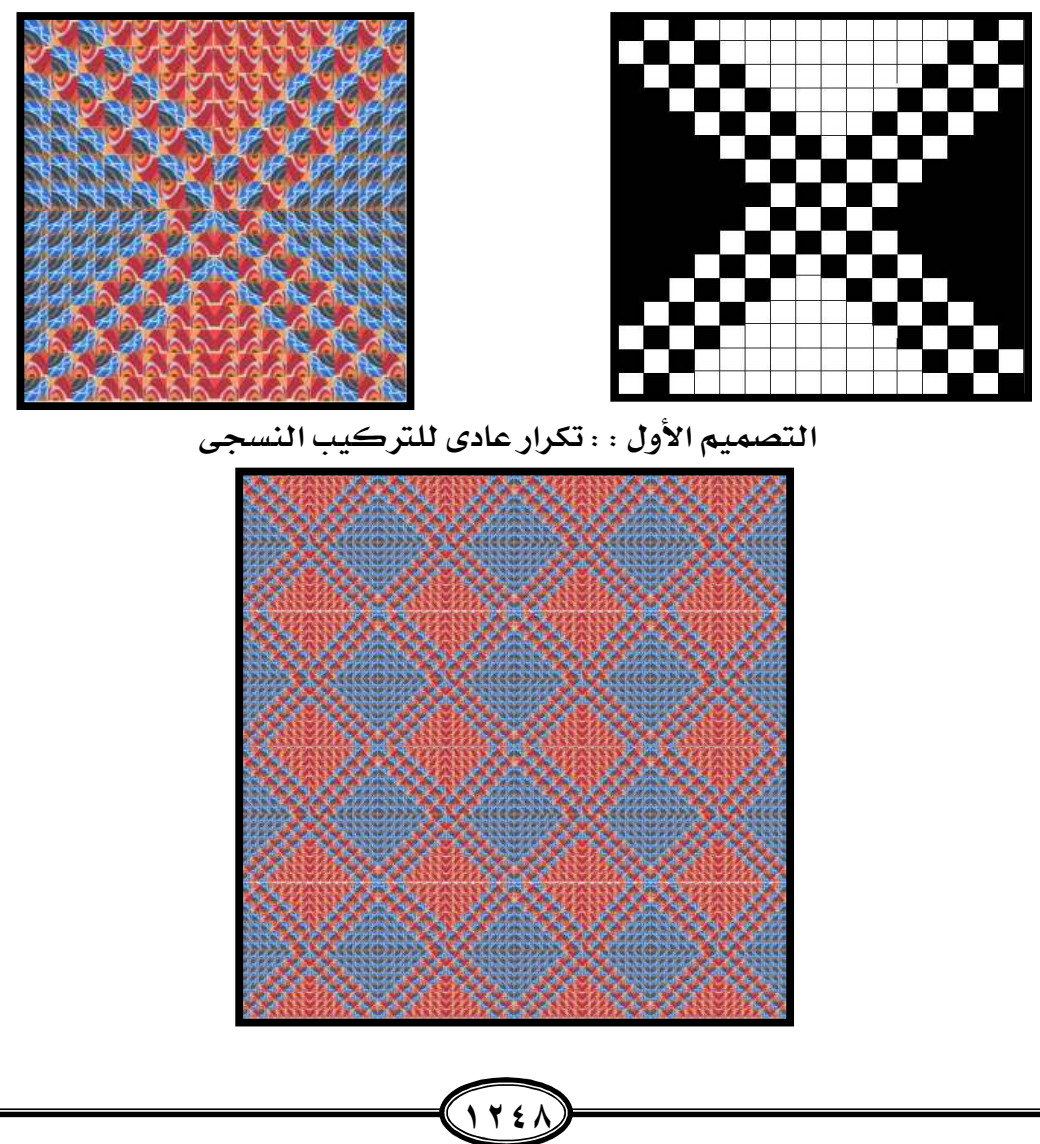


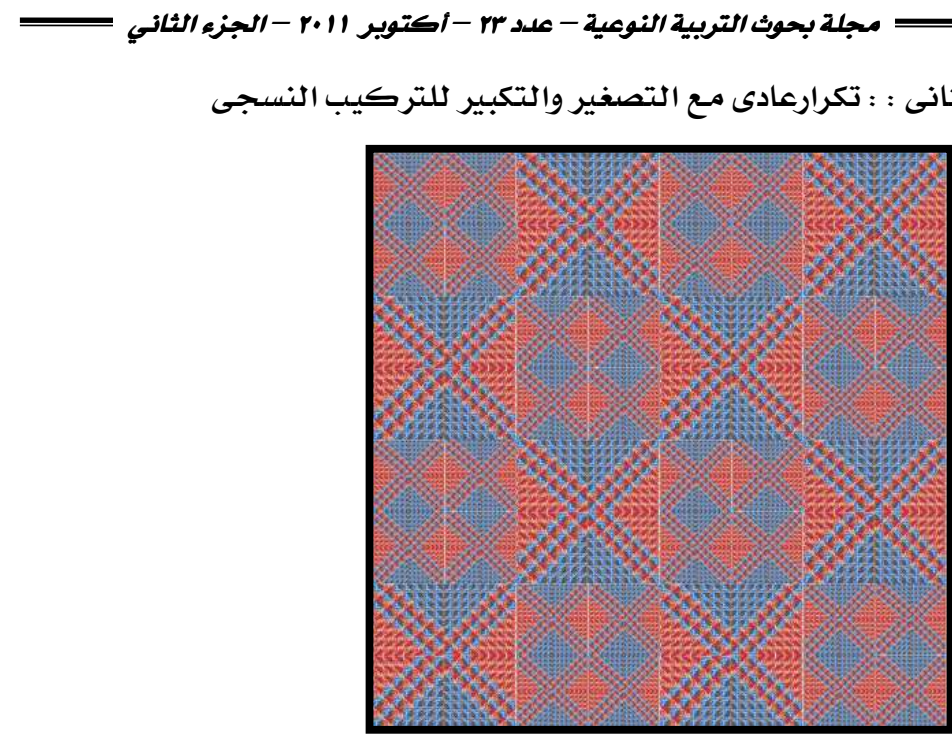

\section{المعلقة النسجية الأولى: - المي}

• التصميهم المستخدم : ناتج عن التركيب النسجى (الضامـة) •

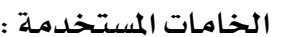

$$
\text { O السداء : خيوط قطن صيادي. }
$$

O اللحمة : خيوط تريكو ․ 1 أكريلك ، خيوط زخرفية. • النول المستخدم : نول البرواز.

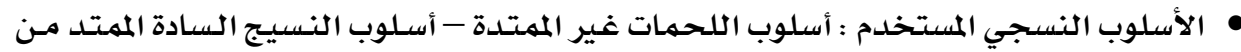

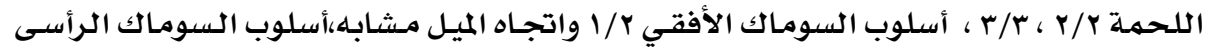

$$
\text { المفرد . أم }
$$

\section{المعلقة النسجية الثانية:}

$$
\text { • • التصميهم المستخدم : ناتج عن التركيب النسجى (مبرد مكسور) }
$$$$
\text { O السداء : خيوط قطن صيادي. }
$$$$
\text { O العقدة : خيوط دارلون . }
$$

O اللحمهة : خيوط قطن صيادي للأرضيـة.

$$
\text { • النول المستخدم : نول البرواز. }
$$

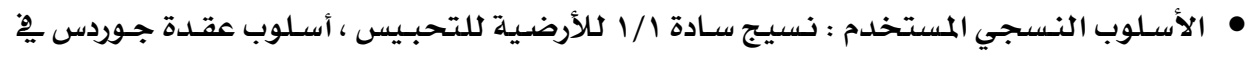



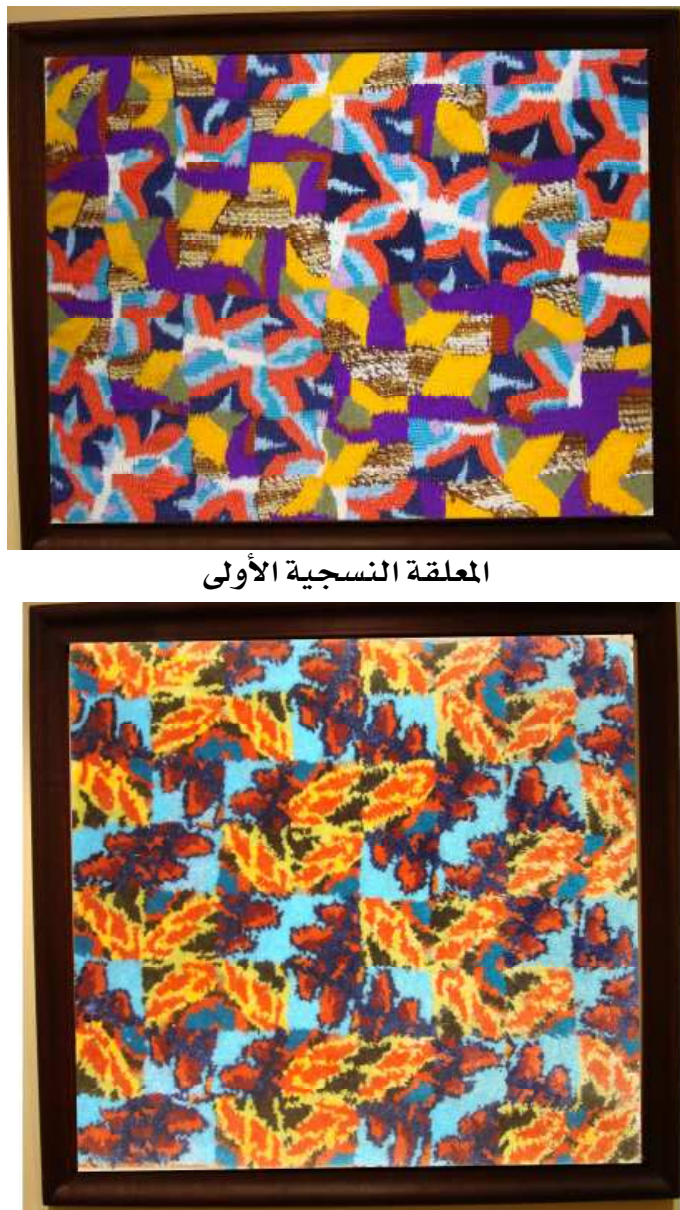

المعلقة النسجية الثانية

المعلقة النسجية الثالثة:

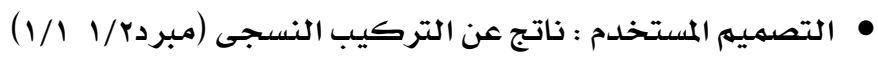
•

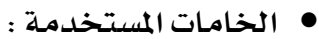

O السداء : خيوط قطن صيادي.

O العقدة : خيوط دارلون :

O اللحمة : خيوط قطن صيادي للأرضية.

• • • • النول المستخدم : نول البرواز.

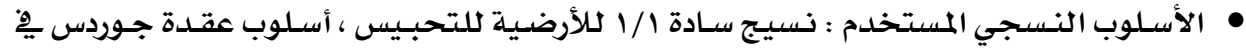

التصميه. 


$$
\begin{aligned}
& \text { • التصميه المستخدم : ناتج عن التركيب النسجى (مبرد r/r) } \\
& \text { • المساحة : .0. }
\end{aligned}
$$

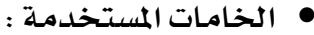

$$
\begin{aligned}
& \text { O السداء : خيوط قطن صيادي. } \\
& \text { O العقدة : خيوط دارلون . } \\
& \text { O اللحمة : خيوط قطن صيادي لتلأرضية. }
\end{aligned}
$$

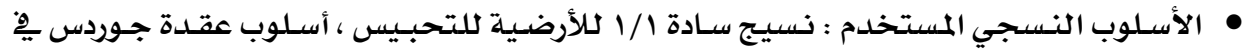

التصميهم.

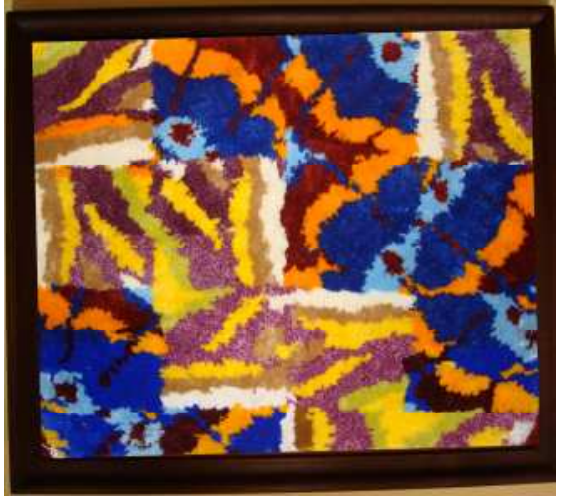

المعلقة النسجية الرابعة

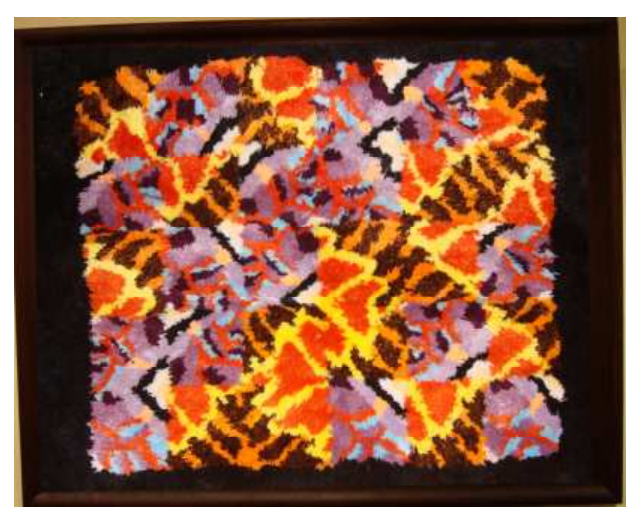

المعلقة النسجيـة الثالثة

نتأُه البحث

توصلت الدراسـة إلى أن :

• التراكيـب النسسجية تـساعد الطـلاب علـى إيجـاد العديـد مـن الحلـول للمسطح التصهيمى

الزخرفى مـن خلال توزيـع المفردات التشكيليـة .

• إعداد تصـيمـات زخرفيـة على أسـاس مـن التراكيـب النسسجية البسسيطة وبـالإعتمـاد على أنواع التكراروأسـس التصميهم يـؤدى إلى الحصول على العديـ مـن القيهم التشكيليـة والجماليـة غير

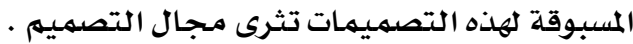

• التصميهم المسبق للعمل النسجى يسـاعد الطلاب على حل الكثير من مشاكل (الأرضية - توزيع

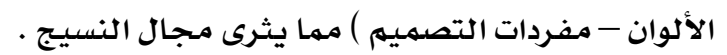
• لايهكن الفصل بين التصميهم والتقنية النسجية فى أعمال النسيج . 


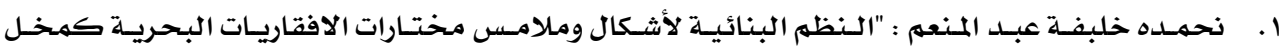
تجريبى لإبتكار مسشغولات فنيـة معاصـرة " رسـالة دكتوراه غير منشورة - كليـة التربيـة الفنيـة - جامعـة حلوان -r. - مبرم.

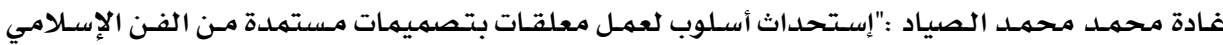
كمدخل لإبتكـار نسسجية مـرسمـة تشكيلات نسجية معاصـرة "- رسـالة دكتوراه غير منشورة - كليـة

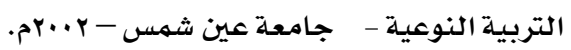

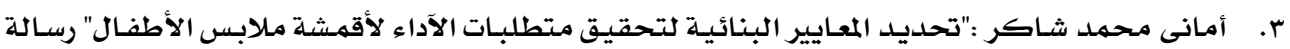

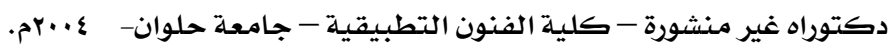

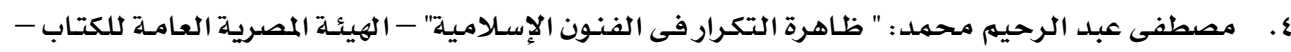
.01998

$$
\text { 0. حسن حموده : " قواعد الزخرفة " - مؤسسة روزاليوسف - القاهرة - . • 199م. }
$$

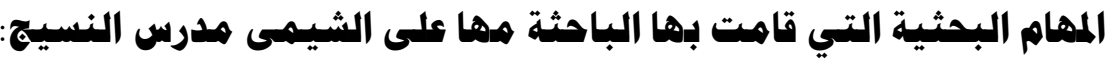

المشاركة فِ جمـع المادة العلميـة / مسكلة الدراسـة / المشاركة فى بنـاء البرنامـج مـن حيـث

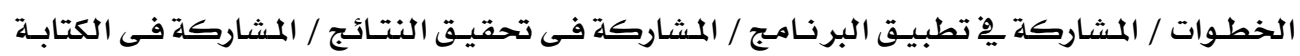
وتنظيهم المراجـع.

\section{المهام البحثية التي قام بهها الباحث هسن هسن طه مدرس التصميم:}

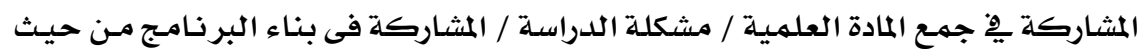

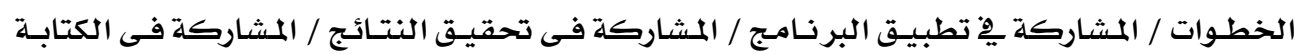

$$
\text { وتنظيم المراجـع. }
$$

